1985

\title{
Symposium Acknowledgements
}

\author{
Various Editors
}

Follow this and additional works at: https://digitalcommons.law.villanova.edu/vlr

Part of the Evidence Commons

\section{Recommended Citation}

Various Editors, Symposium Acknowledgements, 30 Vill. L. Rev. 1311 (1985).

Available at: https://digitalcommons.law.villanova.edu/vlr/vol30/iss6/2

This Symposia is brought to you for free and open access by Villanova University Charles Widger School of Law Digital Repository. It has been accepted for inclusion in Villanova Law Review by an authorized editor of Villanova University Charles Widger School of Law Digital Repository. 


\section{ACKNOWLEDGEMENTS}

The Villanova Law Review wishes to express its gratitude to Judge Arlin M. Adams of the United State Court of Appeals for the Third Circuit for his thoughtful participation in the symposium. Judge Adams addressed the symposium audience and submitted a paper detailing the Third Circuit's jurisprudence on the confluence and conflict between the sixth amendment confrontation clause and the coconspirator exception to the hearsay rule codified in rule 801 (d)(2)(E) of the Federal Rules of Evidence. Judge Adams' commentary was rendered moot, however, by the Supreme Court's reversal of the Third Circuit in United States $v$. Inadi. ${ }^{1}$ Accordingly, Judge Adams' comments do not appear in this issue of the Villanova Law Review.

The Law Review would also like to acknowledge the symposium participation of Professor Walker J. Blakey of the University of North Carolina School of Law.

1. 54 U.S.L.W. 4258 (U.S. Mar. 10, 1986) (No. 84-1580). 
Villanova Law Review, Vol. 30, Iss. 6 [1985], Art. 2 